\title{
INVESTIGATION OF THE FUNCTIONAL DEPENDENCIES BETWEEN MILKING UNIT PULSATION PARAMETERS AND PRESSURE ON AN ARTIFICIAL TEAT
}

\author{
Galina Dineva, Kancho Peychev, Veselin Vlashev, \\ Dimitar Georgiev, Vanya Georgieva \\ Department of Agricultural Engineering, Faculty of Agriculture \\ Trakia University of Stara Zagora, Bulgaria \\ Studentski grad, 6000 Stara Zagora, Bulgaria \\ e-mail: galinats@abv.bg,kvp_sz@abv.bg, vesvlashev@abv.bg, dsgeorgiev@abv.bg
}

\begin{abstract}
The milking units with a triangular shape in cross-section were investigated. The data obtained are related to the structure (time-frequency components) of pulsogramme describing the mode of operation of the respective samples. The pressure is measured performed by milking liner on artificial teat at different parameters of pulsation system. The relationship between pulsation parameters of the milking units and the pressure exerted by them on an artificial teat were studied.

Keywords: milking unit, artificial teat, pressure.
\end{abstract}

\section{INTRODUCTION}

One of the main focuses of applied research in the field of milking technique focuses on changes in pressure pulsation chambers of the milking cups in the frequency range of $1 \mathrm{~Hz}$ to $2,5 \mathrm{~Hz}[2,3]$ and the reaction of the walls of the elastic element - milking liners $[4,5]$.

Differences in the design of milking liners influence the operating parameters of the milking units $[8,11]$. It affects the strength of rendered to teat [1]. That depends on the differential pressure between the milking and pulsation chamber and the amplitude of the milking liners [6].

The pressure at massage and irritation performed by milking liner on papilla not only increases milk production but also affects the secretory activity triggering a chain of reflex reactions of the animal. This is crucial for the normal functioning of organs for breathing, stomach, cardiovascular system, sexual organs and others [12].

According to some authors $[9,10]$ design of milking liner and vacuum optimization is a real opportunity to improve the efficiency of the milking units.

Despite progress in improving milking equipment and applied technology udder health problems continue to focus the attention of scientists and specialists in the field of dairy farming. We must be sought more effective (in terms of the health of the udder) combinations of the pulsation system parameters and the types of milking units. The only normative regulation is an ISO 5707 [7] which allude to minimum values of the individual phases of the pulse as a percentage (\%) of its period, without commenting specific frequency range and pulse fill factor respectively pulsation ratio.

The aim of this study is to establish the relationship between pulsation parameters and exerted pressure from milking membranes (liners) on different length artificial teats. 


\section{IRTTIE}

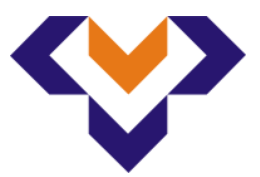

Ipplied Researlohes in Technics, Technologies and Bductition

Journal of the Faculty of Technics and Technologies, Trakia University https:///sites.google.com/a/trakia-uni.bg/artte/

\section{METHODS}

The research was conducted in the laboratory of "Milking machine" of the department Agricultural Engineering at Trakia University of Stara Zagora with milking installation Impulsa M624. The milking membranes with a triangular cross-sectional shape of the company Milk Rite model Ultraliner with a nozzle (integral type) are used. Changes in pulsation rate and ratio is carried out with electronic pulsator. When examining the size of the pressure artificial teats with a diameter of $27 \mathrm{~mm}$ and two lengths: $85 \mathrm{~mm}$ and $110 \mathrm{~mm}$ ware used. They are closed at the upper part where is a discrete opening with a spigot for attachment of the flexible connection (hose). The same is connected to four-channel pulsotester VaDia. The remaining three milking cups are plugged in order to complete pressurization the milking unit. General appearance of the experimental system is shown in Figure 1. Via flexible tube to the device are connected: artificial teat, milking liner head, the short pulsation tube and the short milking tube.

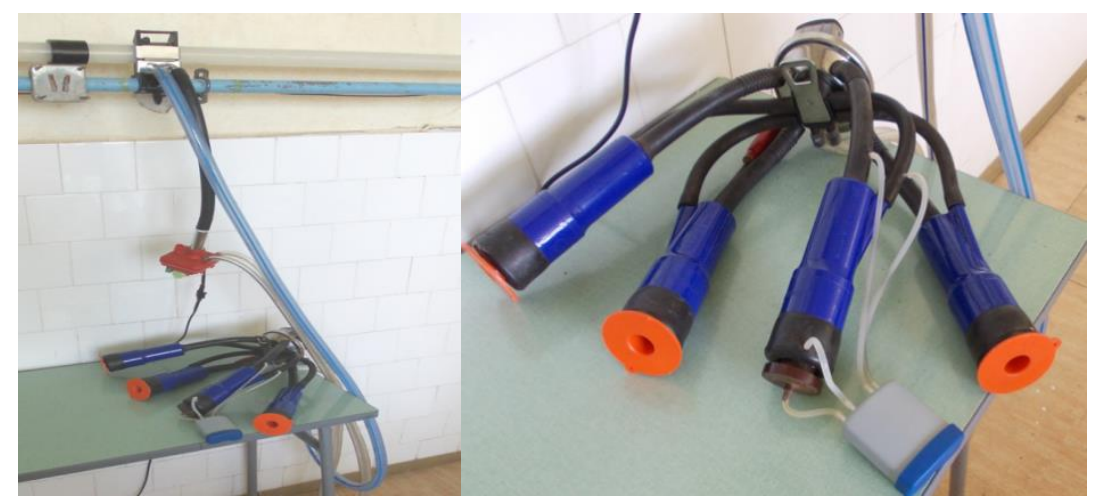

Figure 1. General appearance of the experimental system

Processing and interpretation of experimental data is consistent with the common graphic profile of pulsogramme at ISO 5707 [7], shown in Figure 2.

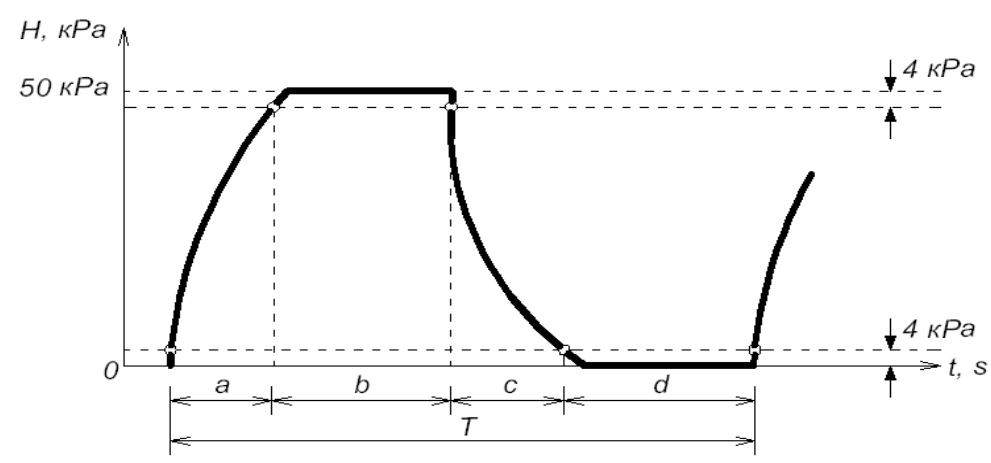

Figure 2. Common graphic profile of pulsograme at ISO standard 5707:

a - the duration of the transition process from atmospheric pressure to a nominal vacuum (front edge of the pulse);

$\mathrm{b}$ - the duration of the phase "a real milking" (vacuum highlands);

$\mathrm{c}$ - the duration of the transition process from the nominal vacuum to atmospheric pressure (rear edge of the pulse);

$\mathrm{d}$ - the duration of the phase "real massage" (atmospheric highlands).

IRTIIE Vol. 4, No. 1, 2016 ISSN 1314-8788 (print), ISSN 1314-8796 (online), doi: 10.15547/artte.2016.01.002 


\section{IRTITE}

Ipplied Researlohes in Technics, Technologies and Bductition

Journal of the Faculty of Technics and Technologies, Trakia University https://sites.google.com/a/trakia-uni.bg/artte/

The period of the pulse $(\mathrm{T})$ is determined by the following expression:

$$
T=t 1+t 2, \mathrm{~ms}
$$

where 11 - duration of tact "milking", ms

t2 - duration of tact "massage", ms.

The duration of tact "milking" (t1) is described by the amount of:

$$
t 1=a+b, \mathrm{~ms}
$$

Within the time pressure into pulsation and milking chamber is aligned and milking liner is in equilibrium - performed tact "milking".

Time massaging effect (t2) on the teat tissue is defined by the amount:

$$
t 2=c+d, \mathrm{~ms}
$$

In the period $\mathrm{t} 2$ pressure into pulsation and milking chamber is different $(\Delta \mathrm{H}=50 \mathrm{kPa})$, a consequence of which the milking liner collapses and makes tact "massage".

\section{RESULTS}

The time pulsation system components are one of the main opportunities to increase productivity and safety of milking equipment. Udder health problems most often associated with inadequate pulsation settings and type of milking liners (membranes).

The vacuum in the milking chamber (measured in head of milking liner and short milk tube) is one of the most important factors associated with the increase of new mastitis infections. At the end of milking tact in the milking chamber exists a negative pressure (vacuum) which may cause backflow milk (fluctuation of milk). In mastitis quarter the backflow milk cause infection and the other udder quarters (cross-infection).

The values of the transition processes are kept almost constant with increasing pulsation rate and ratio (Figure 3). Slight fluctuations occur in phase "a" and they are in the range of 10-12 ms. With increasing ratio can observe an abrupt increase in phase "b". The reason for this asymmetry is created in favor of milking tact.

Increasing the frequency mode of the pulsation system is associated with a reduction in the duration of the phase of the actual milking "b". The rate of reduction is different gradations of the studied frequencies. The largest increase in the frequency of $60 \mathrm{~min}^{-1}$ to $90 \mathrm{~min}^{-1}$.

Experimental data for the duration of the phase "d" are similar but reversed. With increasing pulsation rate the duration of the phase "d" decreases. There was a significant reduction of the phase "d" with an increase in the ratio. This is the result of the established temporary asymmetry, as already noted. It is noteworthy that occur slight fluctuations in phase "b" and "d" in pulse rate $120 \mathrm{~min}^{-1}$. The reason probably is due to the fact that with increasing frequency load establishes contraction in pulsation amplitude. Practically this is reflected in incomplete contraction and dissolution of milking liner and hinder normal course of the two working tacts.

The results in Table 1 show that the pressure measured in the artificial teat almost unaffected by pulsation parameters. Its values are in the range of 5,4 to $6 \mathrm{kPa}$.

IRTIIE Vol. 4, No. 1, 2016 ISSN 1314-8788 (print), ISSN 1314-8796 (online), doi: 10.15547/artte.2016.01.002 


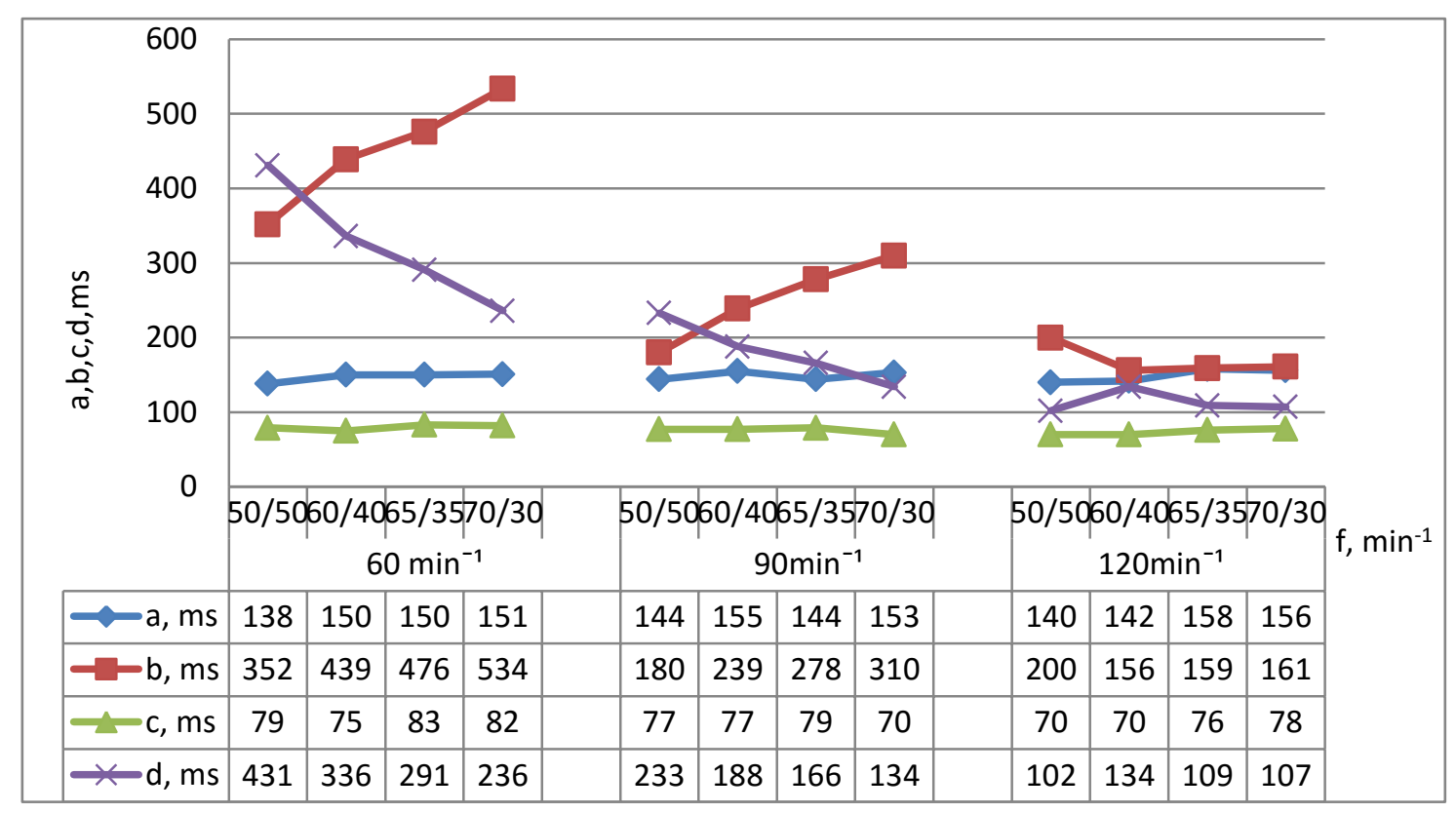

Figure 3. Duration of pulsation phases measured when using artificial teat length $110 \mathrm{~mm}$

Table 1. Vacuum pulsation parameters values of milking unit at an artificial teat with a length of $110 \mathrm{~mm}$

\begin{tabular}{|c|c|c|c|c|c|}
\hline \multirow{2}{*}{$\begin{array}{l}\text { Pulsation } \\
\text { rate }\end{array}$} & \multirow{2}{*}{$\begin{array}{l}\text { Pulsation } \\
\text { ratio }\end{array}$} & \multicolumn{4}{|c|}{ Artificial teat length $110 \mathrm{~mm}$} \\
\hline & & \multirow{2}{*}{$\begin{array}{c}\text { Pressure in } \\
\text { artificial teat } \\
\mathrm{\kappa Pa} \\
\end{array}$} & \multicolumn{2}{|c|}{$\begin{array}{l}\text { Vacuum value of milking } \\
\text { liner head, } \mathrm{kPa}\end{array}$} & \multirow{2}{*}{$\begin{array}{c}\text { Average vacuum } \\
\text { value in short milk } \\
\text { tube }\end{array}$} \\
\hline $\min ^{-1}$ & $\%$ & & $\min$ & $\max$ & \\
\hline \multirow[t]{4}{*}{60} & $50 / 50$ & 5,4 & 12,1 & 41,2 & 46,75 \\
\hline & $60 / 40$ & 5,6 & 12,5 & 42 & 47,65 \\
\hline & $65 / 35$ & 5,5 & 12,5 & 41,5 & 47,15 \\
\hline & $70 / 30$ & 5,7 & 12,7 & 42,1 & 47,6 \\
\hline \multirow[t]{4}{*}{90} & $50 / 50$ & 5,8 & 12,4 & 41,6 & 47,45 \\
\hline & $60 / 40$ & 5,6 & 12,5 & 41,6 & 47,3 \\
\hline & $65 / 35$ & 5,8 & 12,8 & 41,7 & 47,25 \\
\hline & $70 / 30$ & 5,8 & 12,9 & 41,4 & 46,9 \\
\hline \multirow[t]{4}{*}{120} & $50 / 50$ & 5,8 & 12,7 & 40,9 & 46,5 \\
\hline & $60 / 40$ & 6 & 13 & 41,8 & 47,35 \\
\hline & $65 / 35$ & 5,9 & 13,3 & 41,4 & 46,6 \\
\hline & $70 / 30$ & 5,9 & 13,8 & 41,7 & 47 \\
\hline
\end{tabular}




\section{IRTITE}

Ipplied Reseitrones in Technics, Technologies and Bductition

Journal of the Faculty of Technics and Technologies, Trakia University https://sites.google.com/a/trakia-uni.bg/artte/

The minimum and maximum vacuum values in the milking liner head remain almost constant at change the frequency range and ratio. The average vacuum value measured in the short milk tube varies in the range $46-47 \mathrm{kPa}$ and is the result of the operation of the vacuum pump and the reliability of vacuum regulator.

There is a difference in the maximum reported pressure of the milking liner head and short milk tube. This uneven pressure gradient is a prerequisite for the occurrence of backflow milk. It is related to the transfer of microorganisms from common collector milk back to each teat. It is an objective reason for the spread of inflammatory processes between the individual mammary quarters.

The analysis of the pulsation phases is similar to that of an artificial teat length is $85 \mathrm{~mm}$ (Figure 4). The duration of the transitional process is almost the same at change of pulsation settings. By increasing the ratio was observed a sudden increase in the phase "b" and decreasing the phase "d".

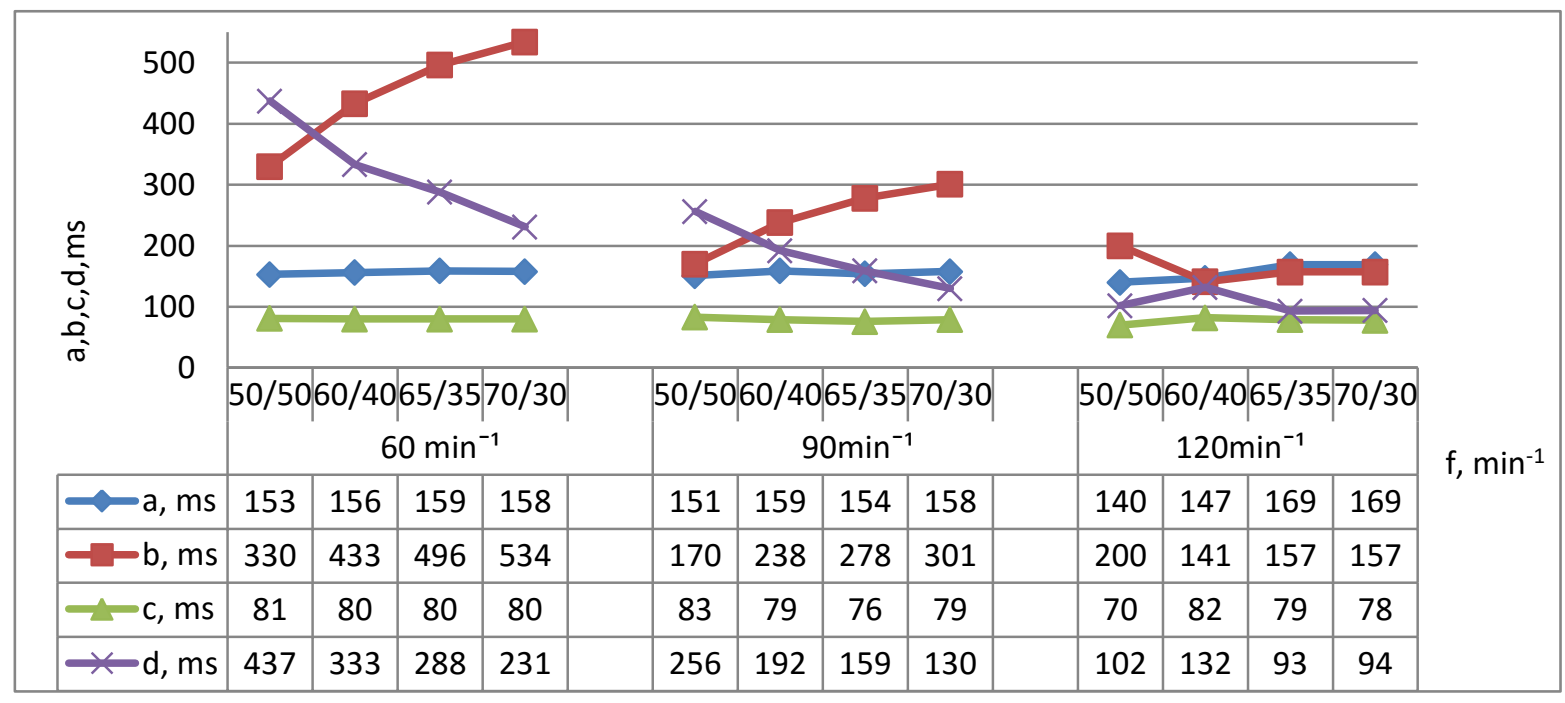

Figure 4.

Duration of pulsation phases measured when using artificial teat length $85 \mathrm{~mm}$

The results (Table 2) show that the pressure obtained in the artificial teat is almost constant and independent of pulsation settings. This value is slightly lower with the use of a shorter teat and is in the range of 5,0 to $5,3 \mathrm{kPa}$.

The minimum and maximum values of the obtained vacuum in the head of milking liner almost not affected by the change of pulsation rate and ratio.

When using shorter teat showed an increase in the minimum values of the vacuum in the milking liner head (Table 2). They are about $6 \mathrm{kPa}$ in comparison with the data obtained for the longest teat (Table 1). On the one hand this would reflect positively on the teat tissue during the massaging phase. On the other hand the rise in pressure is a prerequisite for the occurrence of hyperkeratotic formations. 


\section{IRTITE}

Ipplied Researl'ches in Technics, Technologies ind Bducation

Journal of the Faculty of Technics and Technologies, Trakia University https://sites.google.com/a/trakia-uni.bg/artte/

Table 2. Vacuum pulsation parameters values of milking unit at an artificial teat with a length of $85 \mathrm{~mm}$

\begin{tabular}{|c|c|c|c|c|c|}
\hline \multirow{3}{*}{$\begin{array}{c}\text { Pulsation } \\
\text { rate }\end{array}$} & \multirow{2}{*}{ Pulsation ratio } & \multicolumn{4}{|c|}{ Artificial teat length 110 mm } \\
\cline { 3 - 6 } & & $\begin{array}{c}\text { Pressure in } \\
\text { artificial teat }\end{array}$ & $\begin{array}{c}\text { Vacuum value of milking } \\
\text { liner head, } \mathrm{kPa}\end{array}$ & $\begin{array}{c}\text { Average vacuum } \\
\text { value in short milk } \\
\text { tube }\end{array}$ \\
\hline min $^{-1}$ & $\%$ & $\mathrm{kPa}$ & $\min$ & $\max$ & $\mathrm{kPa}$ \\
\hline 60 & $50 / 50$ & 5,3 & 17,2 & 47,2 & 47,3 \\
\cline { 2 - 6 } & $60 / 40$ & 5,2 & 16,2 & 46,9 & 46,9 \\
\cline { 2 - 6 } & $65 / 35$ & 5,2 & 17 & 47,2 & 47,4 \\
\cline { 2 - 6 } & $70 / 30$ & 5,2 & 17,1 & 47,2 & 47,4 \\
\hline \multirow{2}{*}{90} & $50 / 50$ & 5,2 & 17,6 & 47 & 47,1 \\
\cline { 2 - 6 } & $60 / 40$ & 5 & 17,4 & 46,9 & 47 \\
\cline { 2 - 6 } & $65 / 35$ & 5,2 & 16,4 & 47,2 & 47,4 \\
\hline \multirow{2}{*}{120} & $70 / 30$ & 5 & 16,1 & 46,7 & 47,15 \\
\cline { 2 - 6 } & $50 / 50$ & 5,1 & 17 & 46,7 & 47,1 \\
\cline { 2 - 6 } & $60 / 40$ & 5,1 & 17,3 & 47,2 & 47,3 \\
\cline { 2 - 6 } & $65 / 35$ & 5,2 & 17,5 & 47,2 & 47,4 \\
\hline
\end{tabular}

\section{CONCLUSIONS}

1. The parameters of pulsation system does not affect the pressure in the experimental artificial teat.

2. The length of the teat influences caused pressure inside.

3. The pressure on the tissue of the teat measured indirectly by establishing internal pressure is more pronounced at papilla with greater length.

\section{REFERENCES}

[1] Bade R., Reinemann D., Mein G. (2001). Sources of variability in compressive load applied to bovine teats. [Online], Available: http://www.uwex.edu/uwmril/pdf/MilkMachine/Liners/07\%20NMC\%20CL\%20Variation\%5 B1\%5D.pdf. [2001].

[2] Banev B. (2001). Theoretical analysis of the pulsation vacuum in pulsation system in milking units. Animal Science, No. 2, 2001, pp. 127-130.

[3] Banev B. (2002). Opportunities to increase the critical frequency in pulsation systems in the milking units. Scientific Works SUB - Stara Zagora, "Mathematics and Natural Sciences and Engineering", No. 1, 2002, pp. 291-294.

[4] Banev B., Peychev K. (2001). Experimental studies on the amplitude-frequency characteristics of milking units pulsation system. Animal Science, No. 2, 2001, pp. 131134.

[5] Bechev B., Banev B., Tsvetkov I., Borisov B. (2008). Comparative study of transients in pulsation system in milking units. Agricultural machinery, No. 6, 2008, pp. 8-13. 


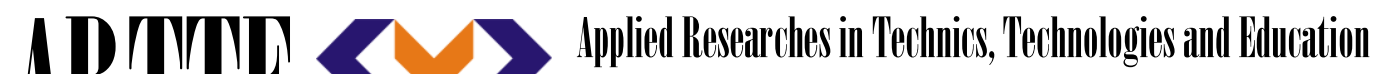 Journal of the Faculty of Technics and Technologies, Trakia University https://sites.google.com/a/trakia-uni.bg/artte/}

[6] Butler M. (1990). A model of relationship between liner movement, liquid flow rate and pressures in a milking machine teatcup. Journal of Agricultural Engineering, v. 46, 1990, pp. 291-305.

[7] ISO 5707 (2007).

[8] Mayer M., Grimm H. (2003). Liner movement: measuring technology and pulsation. Landtechnik, No. 3, 2003, pp. 208-209.

[9] Reinemann D., Mein G. (2011). Unraveling the mysteries of liner compression. Paper presented at the June 2011 Coundown Meeting, Melbourne, Australia.

[10] Spencer S., Rogers G. (1991). Effect of vacuum and milking liners on liner slip. Journal of Dairy Science, v. 74, 1991, pp. 429-432.

[11] Teatcup liners: where the rubber meets the teat. [Online], Available: www.cowtime.com.au.

[12] Vlashev V., Peychev K. (2004). Impact of pulsation rate on exerted pressure by the milking liner on artificial teat. Agricultural machinery, No. 5, 2004, pp. 26-28. 